\title{
Környezeti szennyezéssel érintett ingatlanok értékcsökkenésének meghatározása
}

\author{
Horváth Kálmán
}

DOI: $10.30921 / G K .72 .2020 .5 .4$

Absztrakt: A tanulmány az igazságügyi szakértôi tevékenység keretében vizsgálja a mobilátjátszó-tornyok által a környezố ingatlanok forgalmi értékében bekövetkezett értékcsökkenés rendezésének lehetôségét. Az ingatlanértékelôk a forgalmi értéket a környezet ingatlanpiacának adataival történó összehasonlítással határozzák meg. Alkalmazzák továbbá a költségalapú megközelítést is, amely szerint az ingatlan értéke megegyezik az ingatlanból származó tiszta jövedelem jelenlegi értékével.

Az ingatlan forgalmi értékében bekövetkezett értékcsökkenés mértéke általában megegyezik a tulajdonosi kártérítés mértékével. A tulajdonosok a kártéritést - megegyezés hiányában - bírósági úton tudják érvényesíteni. Az eljáró biróság kirendelö végzésével a szakértô feladatává teszi a peres ingatlanok forgalmi értékének és értékcsökkenésének meghatározását. A tanulmány ismerteti a Kúria néhány figyelemreméltó itéletét, amelyek eseti ítéleti, illetve jogegységi szinten eldöntik a kártérités mértékét.

Abstract: The study examines in the framework of court expert activity the possibility of compensation of turnover value depreciation of the surrounding properties caused by mobile transmission towers. Property appraisers determine the value of the turnover by comparing it with data from the surrounding real estate market. They also apply the cost-based approach, according to which the value of the property is equal to the present value of pure income from the property.

The rate of turnover value depreciation of the property shall be usually equal to the amount of compensation of the owners. The owners can claim the compensation by judicial means in the absence of a settlement. The competent court is acting by appointment of the expert to determine the value and depreciation of the properties under court proceeding.

The study presents some of the most notable judgments of the Curia, which decide the rate of compensation at the level of ad hoc judgment or ruling on legal uniformity matters.

Kulcsszavak: mobilátjátszó-tornyok, ingatlan-értékcsökkenés, kártérítés

Keywords: mobile transmission towers, real estate value depreciation, compensation

\section{Az ingatlanok értékcsökkenésének számszerúsítése}

A szennyezett ingatlanok piaci értékének megállapítására napjainkban már nagy módszertani apparátus áll rendelkezésünkre. Mindennapi életünk egyik releváns problémája a környezettudatosság, így a társadalom és tudomány egyaránt érzékeny a környezetszennyezésre. Az egyes szennyezó források által okozott, különbözô jellegú károsodásoknak az emberekre, a környezetre, a gazdaságra gyakorolt hatását a problémával foglalkozó tudományterületek részletesen vizsgálják. A figyelem azonban egyelôre nem fordult az ingatlanszektor felé, nem ismert széles körben az a hatásmechanizmus, amit egy szennyezô forrás a környezô ingatlanok piaci értékére gyakorol. Ugyanakkor a negatív hatásokat az ingatlantulajdonosok felismerték, így egyre nagyobb számban folyamodnak kártalanításért vagy kártérítésért. A szennyezett - angol nyelvhasználat szerint „stigmatizált” ingatlanok értékcsökkenésének számszerúsítése nemcsak társadalmi szempontból jelentôs, de figyelembevétele nemzetgazdasági döntések elôkészítésénél is elengedhetetlen.

\section{Az értékelést befolyásoló kemény és puha tényezók}

Az EU 2004-es irányelve (2004/35/CE) szerint a környezeti károk megelôzését és felszámolását a „szennyezô fizet" elvének alkalmazásával kell megoldani. E szerint az irányelv szerint a szennyezó az, aki közvetlenül vagy közvetve károsítja a környezetet, vagy aki olyan körülményt hoz létre, vagy olyan létesítményt üzemeltet, amely ilyen károkra vezet. A károkozás, vagyis az ingatlanokat terhelô stigma lehet pl. egy mobilátjátszótorony, egy magasfeszültségú vezeték, repülōtér zajövezete és hulladék-lerakóhely stb. Csoportosíthatjuk az ilyen stigmatizált ingatlanokat a szennyezés fajtája vagy hatása szerint, illetve a harmadik lehetséges csoportosítás a szennyezés időtartama. A szennyezés mértékével kapcsolatos közvélekedés az idôvel változhat, míg a mérési módszerek, technológiák korszerúsödnek, a szennyezési határértékek - a tudomány fejlődésével - egyre pontosabbá válnak, közben a társadalom toleranciaszintje is változik. Egyszerú volna a téma kezelése, ha a stigmatizált ingatlanok értékelését kizárólag a mérhetô és tudományosan magyarázható tényekre építhetnénk. Ugyanakkor az érték legfontosabb változója a társadalmi közeg, amelynek ítélete korról korra, helyszínről helyszínre változik. A tudományosan igazolható tények egy sajátos, társadalmi szúrốn keresztül jelentkeznek, és okoznak változást a piaci értékítéletben, azaz az ingatlanok forgalmi árában. Mindezt a piaci - forgalmi - érték definíciója szempontjából tekinthetjük relevánsnak. A Tegova (The European Group of Valuers) útmutatója a piaci értéket a felek közötti alkuval modellezi, vagyis részben az emberi tényezô felelôs az 
érték kialakításáért. Így a stigmatizált ingatlan forgalmi értéke csak részben magyarázható „kemény” tényekkel, megjelennek a „puha”, a közvetítô társadalmi közegtốl függó értékmódosító tényezôk is. Az ingatlanértékelốk elsôsorban a közvetlen összehasonlításokkal szokták megállapítani a piaci értéket, különösen olyan ingatlanoknál, amelyek nagy számban fordulnak elő a piacon. (Ilyenek a lakóés üdülőingatlanok, építési telkek stb.) A szennyezett ingatlanok esetében az értékmódosító tényezők között megjelenik a stigma, mint a szennyezés „kemény” és „puha” tulajdonságainak együttes értékalkotója. A szennyezett ingatlanokra azonban ez az értékelési megközelítés sok esetben nem alkalmas, ugyanis viszonylag ritka az a tranzakció, ahol egy stigmatizált ingatlan cserél gazdát. Adathiányos esetekre az egyszerú összehasonlító eljárást továbbfejlesztették. A mintateres összehasonlításnál az értékelô azt feltételezi, hogy a helyi ingatlanforgalmat (trendeket és fajlagos árakat stb.) csak egy tényezô, a szennyezés térítette el. Ez azt jelenti, hogy amennyiben egy hasonló, nem szenynyezett terület - a mintatér - forgalmáról tud adatokat szerezni, akkor csak ennek a tényezőnek a figyelembevételére lesz szükség. A mintaterület kiválasztásánál szerepet játszik a fekvés, az épített környezet, a használók összetétele, mindenekelôtt azonban az ingatlanforgalom mutatói. Mintatérként használatos a vizsgált terület szennyezés elótti forgalma, itt korrekciót csak az eltelt idő miatt kell alkalmazni. Vannak olyan esetek, amikor valamilyen elôtanulmányból, kutatásból ismert az értékcsökkenés várható mértéke, amelyet egy specifikus szennyezô forrás okoz. Ilyen például a mobiltelefonátjátszó-torony esete, amelynek a környezô ingatlanokra gyakorolt értékcsökkentô hatásának meghatározására különbözô kutatási eredmények állnak rendelkezésre. Amennyiben az értékelô rendelkezik korábban meghatározott, jól igazolt változókkal, úgy a mintatér forgalmának elemzése magában is elegendô. A stigmatizált ingatlan piaci értékéhez ugyanis el lehet jutni a mintatér összehasonlító adatainak és az értékcsökkenési változónak a különbségeként. Az összehasonlító modellnek a szakirodalomban legtöbbet idézett és vizsgált verziója az úgynevezett „hedonikus” modell. Ennek a többváltozós regressziós megközelítésének az a lényege, hogy az ingatlan értékét különbözô értékalkotókra bontják, ezekhez korrekciós tényezóket rendelnek, amelyek „árnyékárként” kifejezik az egyes értékalkotók súlyát. Amennyiben kellően részletes adatsorok állnak az értékelố rendelkezésére a szennyezett ingatlan környezetének forgalmáról, vagy egy hasonló mintatér forgalmáról, úgy nagy apparátus áll segítségére a stigma által előidézett értékcsökkenés megállapítására. Tényleges tranzakciók hiányában azonban más módszerhez, más megközelítéshez kell folyamodni.

\section{Megközelítések és kockázatok}

Az egyik leghatékonyabb értékelói módszernek tekinthetjük a „költségalapú” megközelítést. Ennek alkalmazásához elengedhetetlen követelmény, hogy a szennyezés és annak negatív hatása - legalább részlegesen - beruházással, illetve múszaki eszközökkel felszámolható legyen. Vannak esetek, amikor a kármentesítés megtörténhet (például a kifolyt szennyező anyag hatástalanítása, eltávolítása). Elốfordulnak más esetek, amikor a kárelhárítás csak részleges (például egy zajvédôfal építésével a zajhatás nem szúnik meg, csak az intenzitása csökken). Az értékcsökkenés számításának az az alapelve, hogy az érintett ingatlanra vonatkozó hatástalanítási beavatkozás költségét mint értékcsökkenést állítjuk szembe az ingatlan - szennyezó hatás nélküli - piaci értékével. Meg kell azonban jegyezni, hogy a teljes hatástalanítás nemcsak a múszaki beavatkozást, hanem az ehhez tartozó kockázatok kezelését, azaz a monitoringot, a hatósági eljárási díjakat, az esetlegesen kiszabott büntetést, az elveszett bevételeket, vagy az elmaradt fejlesztési lehetôséget és a nem fizikai tényezôk (félelem és ellenérzés stb.) kezelését is jelenti, így ezen költségelemek mindegyikét számba kell venni. A költségalapú megközelítésnél fontos ismerni a szennyezôdés idôbeni lefutását, illetve ennek értékmódosító hatását. A költségekkel való közelítés csak bizonyos esetekben követi a piaci viszonyokat. Amennyiben a hatástalanítás viszonylag egyszerúen és véglegesen megtörténhet, és ha ennek költsége lényegesen kisebb, mint az ingatlan értéke, akkor a tapasztalat szerint a piaci szereplốk is ennek alapján számolnak. Tartós, nehezen eltávolítható vagy vitatható mértékú és kiterjedésû szennyezésnél a költségmódszer félrevezetố eredményre is vezethet. A harmadik módszertani csoportként a „hozamszámítással” való piaci érték megállapítása kínálkozik. Ez a módszer azon a befektetôi szemléleten, közgazdasági alapelven nyugszik, amely szerint egy vagyontárgynak (ingatlannak és létesítménynek stb.) annyi az értéke, mint a belőle származó tiszta jövedelmek jelenértéke. Abban az esetben, ha a szenynyezéssel érintett ingatlan a jövedelemtermelố ingatlanok csoportjába tartozik (például a bérbeadással hasznosított ingatlan), úgy a legjobb számítási modellt a jövedelmek csökkenésére lehet felépíteni. Amennyiben például egy lakás rendkívül zajos, úgy azt kell vizsgálni, hogy milyen mértékben csökkennek a piaci bérleti díjak egy átlagos adottságú bérlakás díjához viszonyítva. A szennyezett ingatlanra felírt pénzfolyam eredménye - nettó jelenértéke - a stigmatizált ingatlan piaci értékét adja meg. A szennyezett ingatlannal gyakran magasabb befektetôi kockázat jár együtt, így az alkalmazott tôkésítési kamatláb növekedhet. Amíg a bérleti díjak csökkenését egy szennyezett ingatlannál viszonylag egyszerúen - összehasonlítással, illetve piaci felméréssel - tudjuk megbecsülni, ugyanakkor a befektetôi kockázatok növekedésére nincs adekvát adatbázis. Ennek következtében ez az értékelôi módszer erôs szubjektív becslési elemet tartalmazhat. A hozamszámítás egyik szokásos módja a befektetési célból épült ingatlanoknál a „maradványérték” módszer. Ennek során a várható bevételek idősorával a befektetés költségeit (tervezés, építés és marketing stb.) állítják szembe. Így lehet megközelíteni 
- a szennyezett ingatlan megtisztítási költségének hozzáadásával - a hozamtermelő ingatlan értékcsökkenésének mértékét. Az előző pontban leírt ún. „kevert” módszerben a hatástalanítási költségek és a csökkentett bevételek idôsora egy pénzfolyammodellbe kerül, figyelembe véve a beavatkozással folyamatosan növelhetố bevételtermelő képességet is.

A nemzetközi gyakorlat a stigmatizált ingatlanok esetében egy negyedik értékelési megközelítést is használ, ezt a módszertani csoportot a szakirodalom általában a „nemsztenderd” eljárások gyứjtônév alatt említi. Ezen belül a szakértôi véleménykérés módszerét - jellemzốen - mint gyakorlati eszközt veszik igénybe. A felkért szakértôvel - szakértôi csoporttal, bizottsággal szemben az az elvárás, hogy ismerje a szennyezés fajtáját és annak az ingatlanforgalomra gyakorolt hatását. Ugyanakkor az nem feltétlen követelmény, hogy a szakértô a konkrét eset minden vonatkozását ismerje. Az ingatlantulajdonosok, illetve használok hozzáállásának ismerete már a szociológiai vizsgálatok területére vezet. Ennek alkalmazása esetében ugyanis az érintett ingatlanhasználókat kérdezik meg - nagy mintát alkalmazva az elvárásaikról és értékítéletükrôl. A kérdőíveket szakavatott kutatók állítják össze, egyben tesztelik a válaszok konzisztenciáját is. Nyilvánvaló, hogy a piaci értéket végsố soron a felhasználók, azaz a piaci szereplők alakítják ki. Jól felépített közvélemény-kutatás (lekérdezés) eredményeképpen mindennél tisztábban látszanak azok az értékalkotók, amelyek a stigmatizált ingatlan végsố piaci értékét meghatározzák. Ugyanakkor tisztában kell lenni azzal, hogy ez a módszer költséges, ezért alkalmazása csak kiterjedt szennyeződések esetében látszik reális alternatívának.

A szennyezett ingatlan piaci értékének megállapítására vonatkozó értékelési módszerek tárgyalásánál már utaltunk az alkalmazási korlátokra. A megfelelô módszer vagy módszerek kiválasztása lényegében három dologtól függ. Az adatok rendelkezésre állásától, az ingatlan rendeltetésétôl és a szennyezés típusától. Figyelemmel kell lennünk azonban arra, hogy a projekt költségvetésének függvényében is döntést kell hozni, ugyanis egyes módszerek alkalmazásának jelentôs a költségigénye.

A szennyezett ingatlanok piaci értékének megállapítására nagy módszertani apparátus áll rendelkezésünkre, amelyet nemzetközileg is és hazánkban is eredményesen tudunk alkalmazni. Nyilvánvaló, hogy az ingatlanpiac alaposabb felmérésével és megismerésével az előzőekben tárgyalt módszerek is jobb hatásfokkal múködnek. Ugyanakkor az is egyértelmúen megállapítható, hogy esetenként az értékmegállapításhoz sokkal hosszabb és költségesebb út vezet, mint egy hagyományos értékbecslés esetében.

\section{Igazságügyi szakértó feladata az értékcsökkenés meghatározásában}

Budapest Környéki Törvényszék szakértôt kirendelô végzésében a szakértối faladatot az alábbiak szerint írta elô:

- Határozza meg a perbeli ingatlanok az átjátszótorony megépítését megelôző forgalmi értékét, valamint a forgalmi értéket befolyásoló tényezóket.

- Határozza meg a perbeli ingatlanok jelenlegi forgalmi értékét. Nyilatkozzon, hogy a jelenlegi forgalmi érték meghatározásában melyek a figyelembe veendố szempontok.

- Adjon választ arra, hogy a perbeli ingatlanok jelenlegi forgalmi értékét mi befolyásolja, melyek az ingatlanok tekintetében az értéknövelő, illetve értékcsök kentô hatások, környezeti tényezók.

- Nyilatkozzon a tekintetben, hogy az ingatlanok forgalmi értéke változott-e az átjátszótorony megépítése óta. Amennyiben igen, az miben nyilvánul meg.

A szakértô szakvéleményét helyszíni szemle foganatosítása után terjessze elô. A szemle során részben szemrevételezéssel, illetve amennyiben szükséges, úgy múszeres méréssel határozza meg az átjátszótorony és a felperesi ingatlanok egymáshoz viszonyított helyzetét, a torony láthatósági viszonyait, valamint a láthatóságot befolyásoló domborzati és fedettségi tényezôket. A helyszínen hallgassa meg a peres feleket és a felek jogi képviselőit. Foglaljon állást a peres felek, illetve jogi képviselôik által elôterjesztett kérdések és észrevételek vonatkozásában.

Minden olyan, az épített környezethez nem tartozó - lényegileg környezetidegen - létesítmény, amelynek üzeme, kiterjedése vagy funkciója zavarólag hat a környezetére, az értékcsökkenést idéz elô. Ilyen létesítmények az átjátszótornyok, a magasfeszültségú vezetékek, szélerômúvek, az autópályák és repülôterek stb. Az értékcsökkenés három tényező kölcsönhatásával értelmezhetô:

- az értékcsökkenéssel terhelt ingatlan adottságai;

- a környezetidegen létesítmény jelen esetben az átjátszótorony adottságai;

- a létesítmény, valamint a környezetükben fekvô lakó- és egyéb rendeltetésú ingatlanok kölcsönhatásának vizsgálata.

Az értékcsökkenéssel terhelt ingatlanok adottságai között vizsgálni kell az ingatlanok rendeltetését, használatának módját, építési idejét és esetleges avultságát és egyéb értékcsökkentố tényezőket.

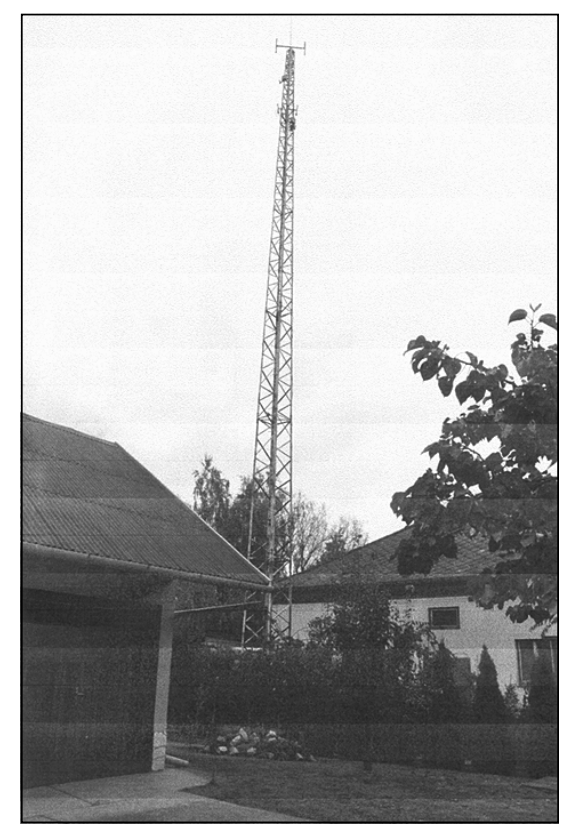

Mobilátjátszó-torony lakókörnyezetben 
Az átjátszótorony, vagy egyéb infrastrukturális létesítmény vonatkozásában vizsgálni kell a létesítmény kiterjedését, a tornyok esetében annak magasságát, múszaki paramétereit, a létesítmény építésének jogszabályi feltételeit, különös tekintettel az elöírt környezeti határértékek betartására, továbbá a létesítmény állagát, esetleges avultságát.

Az értékcsökkenés elemzéséhez meg kell állapítani, hogy az átjátszótorony és a környezetében lévố épületek egymással milyen kölcsönhatásban vannak. Ez a kölcsönhatás lehet kilátáselvonás, illetve kilátáscsökkenés. A létesítményre való rálátás, a létesítmény keltette hang-és fényhatások (erôs szélben zúgó hang, illetve éjszakai kivilágítás), végül, esetenként igen jelentôsen megnyilvánuló tudati tényezôk (idegenkedés, félelem, szorongás és egyéb mentális zavar jelentkezése). Nyilvánvaló, hogy a kölcsönhatások intenzitását alapvetốen befolyásolja a két vizsgált építmény távolsága, valamint a rálátás mértéke.

A kölcsönhatások vizsgálatánál szakértói szempontból relevánsnak tekinthetô annak vizsgálata, hogy az átjátszótorony léte és üzeme menynyire befolyásolja a környezố ingatlanok forgalmi értékét.

Az átjátszótorony jellemzői közül mindenekelőtt a létesítésének helyét kell rögzíteni. A tornyot általában a közigazgatási egység belterületén létesítik, ezen belül is - a nagyobb fedettség biztosítása céljából - a domborzatilag magasabban fekvő helyszínt választják. A torony helyzete az ingatlan helyrajzi számával és vázrajzi (térképi) feltüntetésével egyértelmúen meghatározható. A torony tartozékát képezi a mellette elhelyezett konténer, a térburkolat, kerítés és az esetlegesen létesített támfal. A torony - általában 40-60 m közötti - magassága az építési terven fel van tüntetve, szerkezete rácsos tartós acélszerkezet, általában vörös-fehér színúre festve. A tartószerkezet felsố részén kerülnek elhelyezésre a távközlési antennák és az éjszaki megvilágítást biztosító világítótestek. A torony a magassági helyzete következtében uralja a környezet panorámáját. Ez a magassági helyzet azzal - a per szempontjából releváns - következménnyel jár, hogy az általában néhány száz méter távolságra fekvô felperesi ingatlanok irányából a torony teljes terjedelmében látszik. A láthatóságot befolyásolhatja a felperesi ingatlanok és a torony között lévố terep magassági viszonya, valamint az esetleges - növényzet, légvezetékek tartóoszlopai stb. által elóidézett - fedettség mértéke.

A felperesi ingatlan - több felperes esetében valamennyi felperesi ingatlan - vonatkozásában vizsgálni kell az épületek felmenó falait, a vízszigetelést, az épületek körüli járdát, a teherhordó szerkezeteket, födémeket, a tetôszerkezet kialakítását, a homlokzat kiképzését, a nyílászáró szerkezeteket. A helyiségek vonatkozásában a burkolatot, az oldalfalak kiképzését (festett, tapétázott), valamint a „vizes” helyiségek kialakítását. A lakóépületek fútési rendszerét, melegvízellátását. A lakóépületek alatti pincét, valamint a padlástér esetleges lakótérré alakítását. A lakóházak udvarának hasznosítását, esetleges burkolatát, kocsibejáró kialakítását stb. Az udvaron elhelyezett melléképületek helyzetét, állagát és méreteit. Vizsgálni kell továbbá az ingatlan közmúellátottságát, azaz vízellátását, szennyvízelvezetésének módját, gázellátását, elektromosáram-ellátottságát.

A fố és melléképületeket a szakvélemény mellékletét képezó magyarázó vázrajzon ábrázolni kell. A belsô helyiségekrôl szintenként, méretekkel ellátott alaprajzot kell készíteni, és a belsô méretekből meghatározni a helyiségek „hasznos” alapterületét.

„Az igazságügyi szakértôi vizsgálatok kézikönyve" rámutat arra, hogy a múszaki szakvéleményekkel szemben alapvető követelmény a számszerûség, pontosság és ellenőrizhetőség magasabb szintjének biztosítása. Az ügyben kirendelt szakértônek minden esetben azzal kell számolnia, hogy szakvéleményét a per során további szakértôk is vizsgálni fogják, egyben arra kell törekednie, hogy a szakvélemény megállapításait - a várható fellebbezések során - magasabb fokú bíróságok is megalapozottnak, azaz az ítélet alapjául felhasználhatónak találják.
Az elốzóekben ismertetett vizsgálatok alkalmasak a forgalmi érték meghatározására. A hazai bírósági gyakorlat általában az összehasonlító piaci adatokra épüló forgalmi érték meghatározását tartja követendô és egyben elfogadható módszernek. A hivatkozott módszerrel kimunkált szakértôi értékbecslés annál pontosabb lesz, minél több - és a vizsgált ingatlanhoz minél jobban hasonló - ingatlant tudunk az eljárásba bevonni. Ez a módszer naprakész összehasonlító adatok birtokában általában jól követi az ingatlanpiac alakulását. A módszer alkalmazása - a bírósági gyakorlaton túlmenốen - a piacon jelenlévő ingatlanok (lakások és üdülôk stb.) értékelésének általánosan elfogadott módszere.

Az ingatlanforgalmi érték meghatározása során mindenekelốtt az összehasonlításra rendelkezésre álló piaci adatok halmazát, az úgynevezett alaphalmazt kell vizsgálat tárgyává tenni. Hiteles adatbázisként általában az illetékhivatal forgalmi adatait lehet elfogadni, igazságügyi ingatlanértékelési kérdések vonatkozásában ezek használata kötelezônek tekinthetô. Az illetékhivatal rendelkezésére állnak az adásvételi, ajándékozási és örökösödési stb. jogcímen létrejött tulajdonszerzések adatai. (Ezek az ún. „tranzakciós” adatok.) A szakirodalomból ismert, hogy a vételár és a valós forgalmi érték között létezik ugyan korreláció, de a két adat között szorosabb összefüggés csak nagyszámú tranzakciós minta esetén várható. Kisszámú adatból ugyanis a statisztikai függetlenség és reprezentativitás követelményeit kielégítő következtetést nem lehet levonni.

Az illetékhivatali adatok - felhasználási szempontból - egyéb módszertani problémát is felvethetnek. $\mathrm{Az}$ adatok ugyanis csak az ingatlanok helyrajzi számát, az utcát, a házszámot, a telek területét, valamint a szerzôdésben rögzített vételárat - az illetékhivatal által elfogadott illetékalapot - tartalmazzák. Ugyanakkor a lakóingatlan beépített alapterületére, a helyiségek belsố hasznos alapterületére, továbbá az ingatlan minőségére, használhatóságára, esetleges 
avultságára vonatkozó adatok teljességgel hiányoznak. A hivatkozott hiányosságok következtében, releváns minôsítő jegyek nélkül, ismeretlen tranzakciós háttérrel rendelkezó illetékhivatali alaphalmazt tudunk csak felhasználni. Ezek a problémák és hiányosságok azt eredményezik, hogy az ingatlan értékére csak korlátozottan megalapozott tényállításokat tudunk megfogalmazni.

A szakértô a bírósági kirendelésre elôterjesztett szakvéleményében csak objektív mûszaki tényeket és a tényekbôl levonható következtetéseket terjeszthet elô. A peres ügy eldöntésére vonatkozó mindennemú utalástól, véleménytől tartózkodnia kell. A rendelkezésre álló tények mérlegelése és az ügy eldöntése a bíróság kizárólagos hatáskörébe tartozik.

Az Igazságügyi Múszaki Szakértôi Bizottság (IMSZB) szakvélemény-felülvizsgálati tevékenységében (20042013. év között) előfordult olyan szakvélemény is, amelyben a szakértô a torony építése után öt évvel az értékcsökkenést - részletes indoklás mellőzésével - kizárólag „elektroszmog” -ra hivatkozva a forgalmi érték 35\%ában határozta meg. A 35\%-os értékcsökkenés figyelembevételével egy húszmillió forint forgalmi értéket képviselố családi ház értékcsökkenése hétmillió forintot tenne ki. Ez az értékcsökkenés teljesen irreális, ezt bizonyítja, hogy az eljáró bíróság ítéletében 10 \%-os értékcsökkenést állapított meg.

Az igazságügyi szakértô kiterjedt ingatlanforgalmi információ birtokában alapos vizsgálat és elemzés alapján, legjobb tudása szerint terjeszti elố szakvéleményét, amely azonban sohasem tekinthető „objektív ténynek". Címében is benne van, hogy az előterjesztett munka a szakértő véleménye. A szakvélemény a perben bizonyítékként - bizonyítási eszközként - szerepel, és mint ilyen a bíróság szabad mérlegelésének van alárendelve. A Polgári perrendtartás $(\mathrm{Pp})$ szerint a bíróságnak joga van újabb szakértôt kirendelni, illetve az IMSZB-t - 2013. évtôl MISZT-t felkérni felülvizsgálati szakvélemény, illetve testületi szakvélemény elôterjesztésére.

\section{Kártérítési ügyek bírósági rendezése}

Figyelemreméltó a mobiltornyok által előidézett értékcsökkenés bírósági rendezésében tapasztalható kettôsség, amely a szakértôi és ítélkezési gyakorlat között tapasztalható. A bírósági kirendelô végzések értelmében az ingatlan-értékbecsléssel foglalkozó szakértôknek az ingatlanok forgalmi értékét és a torony által előidézett értékcsökkenés mértékét kell megállapítani. Ez az értékcsökkenés az átjátszótornyok építése és a perek megindítása közötti idôkorlát (általában 2-5 év) miatt reprezentatív forgalmi értékból - a csekély tranzakciós mintára tekintettel - általában ki sem mutatható. A tornyok léte és üzeme ugyanakkor a környezetükben lévố lakóingatlanok terhére olyan „áthatásokat" fejtenek ki, amelyek részben objektív, részben szubjektív formában zavarják a torony környezetében lakó tulajdonosokat. Ezek az áthatások a hatályos jog szerint általában kimerítik a „szükségtelen zavarás” fogalmát, ezáltal a környezô ingatlanok forgalmi értékének csökkenését idézik elô.

$\mathrm{Az}$ ingatlanok értékcsökkenésének meghatározása ingatlanforgalmi szakkérdés. A szükségtelen zavarást elôidézố tényezôk - a torony magassága, a peres ingatlanokhoz viszonyított távolsága, a torony láthatósági viszonyai - meghatározása ugyanakkor inkább földmérôszakértők szakterületéhez tartozik. Ugyanis a földmérôszakértôk a hivatkozott tényezőket pontosabban és szakszerúbben tudják meghatározni. A zavarás szükséges, illetve szükségtelen mértékének megállapítása ugyanakkor a bíróság kizárólagos hatáskörébe tartozik.

\section{A Kúria és az Ítélốtábla ítélkezési gyakorlata}

Szakértôi szempontból is hasznos lehet a Kúria (2012-ig Legfelsôbb Bíróság) ítélkezési gyakorlatának ismerete. Az IMSZB szakvéleményfelülvizsgálati tevékenységében szükségesnek látszott az Ítélőtábla, a Legfelsôbb Bíróság (Kúria) néhány iránymutató eseti ítéletének, illetve a bíróságok részére kötelezô jellegú jogegységi döntésének tanulmá nyozása.

- Legfelsôbb Bíróság Gfv. X. 337/2005/5 sz. ítéletében megállapítja, hogy a két felperesi ingatlan az antennatartó toronytól 200 m-en belül fekszik. A tulajdonosok ellenszenvvel viseltetnek a bázisállomással szemben, félnek a bizonytalantól, a sugárzástól, nagyobb szél esetén a torony fütyülố hangot ad, zavarja a televízió- és rádióadást. A létesítmény a funkciójából adódóan környezetidegen. Az értékcsökkenés függ a toronytól való távolságtól, illetve a rálátás mértékétől. A bíróság hangsúlyozza, hogy önmagában az a tény, hogy az alperes az adótorony felépítésekor a jogszabályi elôírásokat betartotta, nem alkalmas felelôsségének kimentésére. A kimentéshez ugyanis azt kellett volna bizonyítania, hogy az adótorony mint elismerten társadalmi és közcélokat szolgáló beruházás csak az adott helyen volt kivitelezhetô. Nem kimentési alap az alperesnek a gazdaságossági szempontokra, vagyis arra történő hivatkozása, hogy máshol is felépíthetô lett volna az adótorony, csak nagyobb költségráfordítással. A távközlési eszköz által okozott zavarás sérti az ingatlantulajdonosok jogát, ezért az alperes a kártérítési felelősség megállapítása alól nem mentesül.

- Legfelsőbb Bíróság Pf. E. 21935/2005/2 sz. ítéletében megállapítja, hogy a 35 felperes ingatlana az antennatoronytól 175 m-560 m közötti távolságban helyezkedik el. A közérdekból épült technikai berendezéseknek is meg kell teremtenie az összhangot a környezettel. Az alperes olyan helyen létesítette az átjátszótornyot, ahol az infrastruktúra kiépített, és ezzel a kivitelezés a legkisebb gazdasági ráfordítással volt megvalósítható. A közel azonos lefedettség azonban nagyobb távolságra is biztosítható lett volna. A torony az ingatlanforgalmat hátrányosan befolyásolta, létesítésével a Ptk.-ban szabályozott szomszédjogok sérültek. 
Amennyiben a torony üzemeltetésével a szükségtelen zavarás elkerülhetetlen, úgy az alperes nem mentesül a kártérítési kötelezettség alól.

- Pfv. III. 21869/2011/8 sz. ítéletében a Kúria megállapítja, hogy a 31 felperes lakóingatlana közelében létesítette az alperes az átjátszótornyot. A bíróságnak azt kellett figyelembe venni, hogy az értékcsökkenés mértékét több tényezô is befolyásolhatja, és e körben a szubjektív körülményeknek is szerepe lehet. A sugárzástól való félelem, a félelemmel együtt járó ellenérzés és az e körben kialakult közvélekedés befolyásolhatja az ingatlanpiacon az ingatlanok forgalmi értékét, függetlenül attól, hogy a káros egészségügyi hatás természettudományos módszerrel bizonyított-e. A forgalmi érték csökkenését eredményezô közvélekedés tehát egy objektivizálódott tény, amelyen felül nyilvánvalóan figyelembe kell venni az ingatlanok egyéb adottságait, így az egyes ingatlanoknak a létesítménytôl való távolságát is.

- Pfv. III. 21708/2011/4 sz. ítéletében a Kúria megállapítja, hogy az alperes $50 \mathrm{~m}$ magas átjátszótornyot létesített a felperesi ingatlanoktól 290-450 m közötti távolságra. A bíróság az ítélkezés alapjául elfogadta a szakértônek a piaci összehasonlító adatok elemzésén alapuló módszerével meghatározott forgalmi értéket, valamint a létesítmény által okozott, és forgalmi értékcsökkenést eredményező hátrányokat. A bíróság álláspontja szerint mindig az adott ingatlanok és környezetük sajátosságait értékelve kell vizsgálni a zavaró hatásokat és az ezekkel összefüggó forgalmi értékcsökkenést, amelyek bekövetkezésében szubjektív körülményeknek is szerepe lehet. E körben annak van jelentôsége, hogy a sugárzástól való félelem, a félelemmel együtt járó ellenérzés és az e körben kialakult közvélekedés is befolyásolja az ingatlanpiacon az ingatlan forgalmi értékét, mert az ingatlan forgalmi értékére negatív módon hat ki, ezért figyelembevétele nem mellőzhetô. Téves tehát az alperes hivatkozása arra, hogy ez a körülmény „dogmaként” került értékelésre, mert a forgalmi értékcsökkenést eredményezố közvélekedés egy objektivizálódott tény.

- Ítélôtáblák elvi állásfoglalásai (Bírósági Döntések Tára 2013/4/53)

I. A szomszédjogi sérelemre alapított, a szükségtelen zavarástól való tartózkodás tilalmának megsértésével keletkezett károk megtérítése iránti követeléseket a szerzôdésen kívül okozott károkért való felelôsségre vonatkozó általános szabályok alapján kell elbírálni.

II. Az üdülố- és lakóingatlanok közvetlen közelében épített fémszerkezetû́ mobilátjátszó-torony több szempontból és jelentôs mértékben zavarja a szomszédos ingatlanok használóit, amely zavarás az észszerú tûrési határokon kívül esik.

A zavarás jogkövetkezményeként elégséges és arányos, ha a birtoklásában zavart fél vagyoni kompenzációt kap; a jelentôs költséggel megvalósult közérdekú beruházás esetén túlzó, aránytalan és szükségtelen az építmény elbontása.

III. Az értékcsökkenésben jelentkezô kár nem szúkíthetố le az ingatlan forgalmi értékének csökkenésére. Az olyan ingatlan használati értéke, amelynek közvetlen közelében egy magas, fémszerkezetû mobilátjátszó-torony létesült - a zavarás ténye folytán - alacsonyabb, mint amelynek közelében ilyen nem épült, és a zavaró hatás nem érvényesül. A vagyoni hátrány akkor is beáll, ha egyéb tényezôk miatt az ingatlanforgalom csekély, a forgalmi értékvesztés adatokkal nehezebben alátámasztható.

Az ítélôtáblák elvi állásfoglalásai és eseti döntései iránymutatók az ítélőtáblák, a törvényszékek, valamint a városi és járási bíróságok részére.

Az I., II. és III. alatt közölt állásfoglalásokat szó szerint idéztem.
A Legfelsôbb Bíróság és a Kúria hivatkozott ítéleteiból az állapítható meg, hogy az átjátszótoronytól 500 m-en belül fekvố ingatlanok vonatkozásában a megállapított értékveszteség a forgalmi érték 10\%-a, míg az 500-1000 m között fekvô ingatlanok vonatkozásában a megállapított értékcsökkenés a forgalmi érték 5\%-a. 1000 m-nél nagyobb távolságra fekvô ingatlanok vonatkozásában értékcsökkenés nem került megállapításra. Amennyiben a felperesi ingatlanok területérôl a torony csak részben látszik, úgy a megállapított értékcsökkenés - a láthatóság mértékében - 1-2\% módosítására került sor.

A hivatkozott Legfelsôbb Bíróság, valamint a Kúria ítéleteit lényegileg szó szerint (lerövidítve) közöltem, így lehetôségünk van a bírói fórumok mû́szaki szövegezéstôl és indoklási módtól eltérố - jogi nyelvezetének, érvelésének és ítéleti indoklásának tanulmányozására.

A szerzô 1957-tôl igazságügyi szakértő, 2004-2013. között az Igazságügyi Múszaki Szakértôi Bizottság elnöki teendốit látta el.

\section{Irodalom}

Horváth Kálmán - Hajnal István 2014 Value Impairment of Contaminated Real Estate. Periodica Polytechnica. Social and Management Sciences. Budapest DOI: $10.3311 /$ PPso. 7389

Horváth Kálmán 1995. A földmérô szakértôi munka szempontjai a peres eljárásban. Geodézia és Kartográfia. 47. évf. 3. sz. Budapest.

Molnár Gyula 1976. Az igazságügyi szakértôi vizsgálatok kézikönyve. Budapest.

Rácz Zsolt 2007. Mobil hálózatok hatósági szempontból. Igazságügyi Szakértô VI. évf. 2. sz.

Thuróczy György 2007. Az elektromágneses terek környezet-egészségügyi kérdései a mobiltelefon bázisállomások témakörében. Igazságügyi Szakértő VI. évf. 2. sz. Bírósági Határozatok (BH) 2005. és 2011. Bírósági Döntések Tára (BDT) 2013.

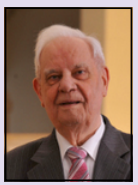

Dr. Sc. Horváth Kálmán professor emeritus

BME Általános és Felsôgeodézia Tanszék horvath.kalman@index.hu 